\title{
Облік та оцінка земельного потенціалу України у світовій статистиці: глобальні перспективи та застереження
}

\begin{abstract}
Важливим чинником формування позитивного іміджу краӥни є повночінне представлення на мові ијифр активів, щуо формують ї̈ економічний потенціал. Для Украӥни таким активом у першу чергу є землі сільськогосподарського призначення. Стаття присвячена виріменню проблеми відображення земельного потенціалу Украӥни у фінансовій та статистичній звітностях $з$ точки зору перспектив включення його до глобальної економічної статистики для покрашення іміджу Украӥни у світі. Обтрунтовано застереження щодо ігнорування питань обліку земель у макроекономічній статистиці та наслідків такого ігнорування при відкритті ринку сільськогосподарських земель в Україні. Доведено, щзо вартість землі на рівні з іншими основними засобами формує вартість основного капіталу України. Розкрито місие земельних активів у системі національних рахунків. Встановлено, щуо сільськогосподарська земля не має достовірної оцінки та повного відображення у фінансовій звітності, що прямо впливає на розмір наиіонального багатства Украйни, яке представлене в системі національних рахунків, які $\epsilon$ основним джерелом інформачії про Украӥну у світі. Проведені авторами розрахунки $\epsilon$ глобальним застереженням щзодо вільного ринку землі. Адже капіталізація транснаціональних компаній свідчить, щуо у них достатньо ресурсів, щоб викупити усі украйнські землі, і таким чином позбавити украӥнських фермерів доступу до земельних ресурсів. У зв'язку з ичим наголошується, щзо вільний ринок земель у теперішніх економічних умовах не забезпечить адекватну иіну землі і одночасно нового продуктивного інвестора. Оскільки він буде визначати свою активність та ичіну за поточною дохідністю. Активність і вища иуіна для продавия, наразі, можлива лише від олігархічного покупия, потенційного спекулянта землею чи покупия, який розглядає землю як скарб.
\end{abstract}

Ключові слова: сільськогосподарські угіддя; оцінка землі; облікова політика; рентний дохід, система національних рахунків; фінансова звітність; статистика.

Постановка проблеми у загальному вигляді та іiї зв'язок 3 важливими практичними завданнями. Повноцінне представлення України у світовому інформаційному просторі $є$ одним із ключових факторів покращення іiі іміджу у міжнародній спільноті. Глобалізація економіки, стрімкий розвиток інформаційних технологій суттєво посилює значення звітної та статистичної інформації у формуванні позитивного іміджу України у світі. Тому питання повноти такої економічної статистики потребує досконалого дослідження з вивченням передових європейських практик та світового досвіду.

Важливим чинником формування позитивного іміджу є повноцінне представлення національних особливостей, національного бренда i, врешті-решт, це представлення усього наявного потенціалу країни у світових статистичних базах даних та рейтингах. Для України - це в першу чергу ії земельний потенціал. Наша країна належить до категорії країн світу з найбільшою часткою сільськогосподарських угідь - 71 \% загальної площі країни. За цим показником Україна займає 17 місце серед 263 країн світу, що аналізуються Світовим банком [1].

Аналіз останніх досліджень та публікації, на які спирається автор. Питання обліку та оцінки земельного потенціалу України на рахунку праць Н.Голуб, І.Замули, С.Остапчука, А.Третяка, В. Шевчука, Ю.Дехтяренка, О.Драпіковського, В.Заяця, І.Іванової, М.Лихогруда, Ю.Манцевича, Ю. Палехи, О.Шпичака.

Постановка завдання (формулювання мети статті). Мета публікації - посилити увагу до питання відображення земельного потенціалу України у фінансовій та статистичній звітності як перспективи включення його глобальної економічної статистики для покращення іміджу України у світі. Важливо висловити застереження щодо ігнорування питань обліку земель у макроекономічній статистиці та наслідків такого ігнорування при відкритті ринку сільськогосподарських земель в Україні.

Викладення основного матеріалу. Інформація про Україну у світі великою мірою формує ії імідж. Якщо інформації нема, або вона $є$ неповною, то відповідно і потенціал України (економічний, інвестиційний тощо) суттєво недоццінений. Офіційна глобальна економічна статистика будується на системі національних рахунків (СНР). СНР - це міжнародно узгоджений стандартний набір рекомендацій щодо формування заходів економічної діяльності. СНР описує узгоджений, послідовний та 
інтегрований набір макроекономічних рахунків у контексті набору міжнародно узгоджених концепцій, визначень, класифікацій та правил бухгалтерського обліку. Крім того, СНР надає огляд економічних процесів, фіксуючи розподіл виробництва серед споживачів, бізнесу, уряду та зарубіжних країн.

Отже, національні рахунки є однією зі складових макроекономічної статистики, що є основою для економічного аналізу та формування політики. СНР призначена для використання всіма країнами, розроблена з урахуванням потреб країн на різних етапах економічного розвитку. Вона також забезпечує всеосяжну основу для стандартів в інших галузях економічної статистики, сприяючи інтеграції цих статистичних систем для досягнення узгодженості з національними звітами [2].

В Україні їх складання здійснюється на основі міжнародного стандарту Системи національних рахунків (СНР 2008) та Європейської системи національних і регіональних рахунків (ESA 2010), які прийняті: Європейською комісією, Міжнародним валютним фондом, Організацією економічного співробітництва та розвитку, Організацією Об’єднаних Націй, Світовим банком.

Однією 3 найзначніших глобальних інформаційних інституцій є Світовий банк, економічна статистика якого також будується на СНР.

2008 рік - це 4 оновлення міжнародної СНР. Перший набір стандартів опублікований в 1953 році, після чого були оновлення в 1968, 1993 і останні у 2008 році. СНР є міжнародно узгодженим стандартним набором рекомендацій щодо узагальнення показників економічної діяльності країни. Вона описує послідовний та інтегрований набір макроекономічних рахунків на основі узгоджених на міжнародному рівні концепцій, класифікацій та правил обліку.

Тобто українські показники є зіставними 3 міжнародними, і те, що ми бачимо в системі наших національних рахунків, представлене в інформаційних ресурсах міжнародних інституцій, або буде представлене, коли Україна стане повноправним членом СС.

Такими ресурсами $є$ :

- $\quad$ глобальна статистика ООН, розміщена на сайті ії статистичного відділу. Тут вже є національні рахунки України, зокрема показники ВВП, виробництво, валова додана вартість та основні засоби за галузями у поточних цінах (ISIC Rev.3) (https://unstats.un.org/unsd/snaama/Basic);

- статистика Свросоюзу на сайті Євростату (https://ec.europa.eu /eurostat/web/main);

- статистичні дані на сайті Організації економічного співробітництва та розвитку, що також містять українські дані (https://w3.unece.org/PXWeb2015/ pxweb/en/STAT/STAT_20-ME_2-MENA/);

- база даних Світового банку, зі значним масивом інформації про розвиток усіх країн світу, в тому числі і України (https://databank.worldbank.org).

Проведений аналіз засвідчив, що національна економічна статистика не повною мірою сприяє формуванню позитивного іміджу України у світі. Повертаючись до питання представлення земельного потенціалу України у макроекономічній статистиці, слід зазначити, що землі сільськогосподарського призначення взагалі не відображені в СНР у вартісному вираженні. За нашими розрахунками національне багатство України, у зв'язку з цим, занижене на 25 млрд дол. в поточних ринкових цінах.

Місце земельних активів у СНР слід шукати у складі основного капіталу. В цілому серед національних рахунків в Україні виокремлюють: рахунки виробництва, доходів, споживання, нагромадження капіталу та фінансів. Основний капітал у СНР групується, виходячи 3 міжнародної практики та згідно з міжнародними рекомендаціями вимірювання капіталу,за такими видами:

- житлові будівлі;

- нежитлові будівлі та споруди (з урахуванням витрат на поліпшення матеріальних невироблених активів, включаючи землю, та витрат, пов'язаних із передачею прав власності на невироблені активи);

- машини й обладнання;

- культивовані активи (довгострокові біологічні активи тваринництва і рослинництва);

- нематеріальні основні засоби: витрати на розвідування корисних копалин; засоби програмного забезпечення; інші [3].

Отже, вартість землі на рівні з іншими основними засобами формує вартість основного капіталу України. Інформація про його розмір формується на підставі статистичної та фінансової звітності підприємств і узагальнюється на рахунках капіталу в СНР у «Балансі активів і пасивів». У нас він називається експериментальний саме через те, що в ньому не врахована вартість землі через відсутність їі оцінки, а також майна домашніх господарств (з тієї ж причини).

Баланси активів i пасивів складають для інституційних секторів згідно 3 Класифікацією інституційних секторів економіки України [4], економіки в цілому та іншого світу за нефінансовими і фінансовими активами.

Для інституційного сектору баланс активів і пасивів показує вартість усіх активів - нефінансових і фінансових, а також зобов'язання та чисту вартість капіталу по сектору. Для економіки в цілому такий баланс складається для розрахунку національного багатства. У балансі відображаються всі види економічних активів. За аналогією з рахунками нагромадження активи відображаються в лівій частині 
балансу, а пасиви й чиста вартість капіталу - в правій. Балансуючою статтею є чиста вартість власного капіталу, що розраховується як різниця між вартістю всіх активів і вартістю пасивів. Чиста вартість власного капіталу в економіці в цілому становить національне багатство країни, обсяг якого розраховується у вартісному виразі в ринкових цінах, які діють на момент оцінки активів.

Для складання таких балансів методологічні положення Держстату [3] надають джерела інформації, в основі яких знаходиться статистична i фінансова звітність підприсмств, фінансових установ i бюджетних організацій, а також банківська статистика, статистика платіжного балансу. А отже те, що сільськогосподарська земля не має достовірної оцінки та повного відображення у фінансовій звітності прямо впливає на розмір національного багатства України, що представлене в СНР, які є основним джерелом інформації про Україну у світі.

Тобто на сьогодні розмір національного багатства занижений як мінімум на вартість сільськогосподарської землі, яка поза бухгалтерським обліком.

Як одну з причин слід вказати низьку дисципліну бухгалтерів у виконанні національних положень (стандартів) бухгалтерського обліку. На початку 2000-х рр. Україна імплементувала МСФЗ. В цілому національні стандарти ідентичні МСФЗ. Проте анкетування бухгалтерів аграрних підприємств виявило й інші проблеми. В анкетуванні взяло участь понад 3000 бухгалтерів по всіх регіонах України. Анкетування відбулося на початку 2018 р. у межах семінарів-навчань, що періодично проводяться професійним бухгалтерським об'єднанням - Федерацією аудиторів, бухгалтерів і фінансистів агропромислового комплексу України. Мета опитування - виявлення причин низького відображення в бухгалтерському обліку земельного потенціалу підприємств. За результатами анкетування встановлено відсутність суттєвих розбіжностей у відповідях бухгалтерів підприємств з різним банком землі (було проведено групування до 1000 га; від 1000 до 5000 га; понад 5000 га). На означення причин, з яких не ведеться облік землі та прав на їі використання отримано відповіді:

- відсутність мотивації і контролю від державних інституцій є причиною для 72 \% опитаних;

- відсутність мотивації від власників - $72 \%$;

- висока вартість процедури експертної оцінки для взяття земельних активів на баланс - $91 \%$;

- низька регламентованість процедур оцінки та обліку земельних активів у національних бухгалтерських стандартах, відсутність відповідних методичних рекомендацій - 98 \%;

- незіставність оцінки цих активів за стандартами і «тіньовим» ринком - $48 \%$

Вирішення проблеми очевидне: МСФЗ можна і потрібно адаптовувати як до галузевих, так і до національних особливостей. Більше того, при такому адаптуванні необхідно напрацювати та прийняти єдину облікову політику на основі сдиної методології оцінки для включення землі до системи національних рахунків у реальних показниках вартості. Адже повторимось, дані фінансової звітності основа економічної інформації, найбільш поширене джерело статистичних даних про діяльність суб’єктів господарювання.

Така облікова політика та оцінка мають відображати природну цінність і родючість землі. У вартості має бути врахований і ринковий фактор, і фактор родючості, і фактор економічної ефективності іiі використання в сільськогосподарському виробництві, а не як об'єкта оренди.

Глобальна перспектива запровадження такої облікової політики щодо усіх сільськогосподарських земель - це зростання вартості національного багатства України, за нашими розрахунками, на 25 млрд дол. Така вартість розрахована шляхом застосування методу капіталізації рентного доходу в масштабах усієї ріллі України. Цей методичний підхід $\epsilon$ найбільш прийнятний щодо сільськогосподарських земель, оскільки враховує цінність землі як природного фактора сільськогосподарського виробництва. Саме рентний дохід враховує типовий для місцевості набір культур, а також ціни його реалізації на ринку. Одержані показники дозволяють врахувати у вартості 3 одного боку найбільш ефективне використання, дотримання сівозміни і збереження родючості землі, а 3 іншого - ринкові ціни.

Під час розрахунків було використано діючу методику [5] і дані Держстату (табл. 1).

За запропонованого підходу до визначення справедливої вартості земельних активів за результатами розрахунків у цілому по Україні одержано показники, які близькі до нормативно-грошової оцінки та цін тіньового ринку. Оцінка 1 га ріллі за галузевим стандартом - 1078 дол. США, за нормативно-грошовою оцінкою - 1138 дол. США, тіньового ринку - 1250 дол. США (тобто відхилення у межах 5-8 \%). Оцінка 1 га права оренди за галузевим стандартом - 525 дол. США, на тіньовому ринку - від 200 до 800 дол. США.

Потенційну вартість сільгоспугідь України у фінансовій звітності наведено в таблиці 2, що підтверджує глобальну перспективність застосування нової облікової політики щодо землі сільськогосподарського призначення для подальшого покращення іміджу України у світовій статистиці. 
Джерела інформачії та порядок розрахунку вартості ріллі для відображення у фінансовій звітності та державній статистиці

\begin{tabular}{|c|c|c|c|}
\hline № 3/П & Показник & Розрахунок /значення & Джерело інформації \\
\hline 1. & $\begin{array}{c}\text { Вартість земельної } \\
\text { ділянки, визначена } \\
\text { шляхом прямої } \\
\text { капіталізації рентного } \\
\text { доходу } \\
\end{array}$ & $\begin{array}{c}\text { Відношення рентного доходу } \\
\text { до ставки капіталізації }\end{array}$ & Розрахунково \\
\hline 2. & Рентний дохід & $\begin{array}{c}\text { Різниця між очікуваним } \\
\text { (валовим) доходом від } \\
\text { продукції, виробничими } \\
\text { витратами та прибутком } \\
\text { виробника }\end{array}$ & Розрахунково \\
\hline 3. & $\begin{array}{c}\text { Типовий набір культур, } \\
\text { що забезпечує iіi } \\
\text { ефективне використання, } \\
\text { дотримання сівозміни і } \\
\text { збереження родючості } \\
\text { землі }\end{array}$ & $\begin{array}{l}\text { На основі структури посівних } \\
\text { площ с.- г. культур по регіону }\end{array}$ & $\begin{array}{c}\text { Статистичний збірник } \\
\text { «Сільське господарство» }\end{array}$ \\
\hline \multirow[t]{2}{*}{4.} & \multirow{2}{*}{$\begin{array}{c}\text { Очікуваний (валовий) } \\
\text { дохід від продукції: } \\
\text { - нормальний } \\
\text { (типовий) врожай } \\
\text { сільськогосподарських } \\
\text { культур; } \\
\text { - ціна реалізації с.-г. } \\
\text { продукції на ринку }\end{array}$} & \multirow[t]{2}{*}{$\begin{array}{c}\text { Очікуваний (валовий) дохід } \\
\text { розраховується як добуток } \\
\text { урожайності та ціни реалізації }\end{array}$} & $\begin{array}{c}\text { Статистичний бюлетень } \\
\text { «Площі, валові збори та } \\
\text { урожайність } \\
\text { сільськогосподарських } \\
\text { культур, плодів, ягід та } \\
\text { винограду» } \\
\end{array}$ \\
\hline & & & $\begin{array}{c}\text { Статистичний бюлетень } \\
\text { «Реалізація продукції } \\
\text { сільського господарства } \\
\text { сільськогосподарськими } \\
\text { підприємствами» }\end{array}$ \\
\hline 5. & Виробничі витрати & $\begin{array}{c}\text { Виробнича собівартість с.-г. } \\
\text { продукції }\end{array}$ & $\begin{array}{c}\text { Статистичний бюлетень } \\
\text { «Витрати на виробництво } \\
\text { продукції сільського } \\
\text { господарства в } \\
\text { сільськогосподарських } \\
\text { підприємствах» } \\
\end{array}$ \\
\hline 6. & Прибуток виробника & $\begin{array}{c}\text { Прибуток виробника } \\
\text { визначається як відсоток } \\
\text { загальних витрат продукції, } \\
\text { одержаної на земельній } \\
\text { ділянці. } \\
\text { Ставка розраховується як сума } \\
\text { відсоткової ставки за } \\
\text { кредитами і депозитами у } \\
\text { національній валюті } \\
\text { (середньозважені в річному } \\
\text { обчисленні, \%) }\end{array}$ & $\begin{array}{l}\text { Фінансова статистика НБУ. } \\
\text { Розділ } 4 \text { «Фінансові ринки» }\end{array}$ \\
\hline 7. & Ставка капіталізації & $\begin{array}{c}\text { Прийнята на рівні безризикової } \\
\text { ставки - відсоткова ставка за } \\
\text { депозитами нефінансових } \\
\text { корпорацій (середньозважена } \\
\text { відсоткова ставка в річному } \\
\text { обчисленні) }\end{array}$ & $\begin{array}{l}\text { Фінансова статистика НБУ. } \\
\text { Розділ } 4 \text { «Фінансові ринки» }\end{array}$ \\
\hline
\end{tabular}

Джерело: узагальнено на основі методики [5] 
Табличя 2

Потениійна вартість сільгоспугідь України у фінансовій звітності та системі національних рахунків

\begin{tabular}{|c|c|c|c|}
\hline $\begin{array}{c}\text { Земельний } \\
\text { капітал/активи }\end{array}$ & $\begin{array}{l}\text { Площа, } \\
\text { млн га }\end{array}$ & $\begin{array}{c}\text { Розрахована вартість для } \\
\text { відображення у фінансовій } \\
\text { звітності, } \\
\text { млрд дол. США } \\
\end{array}$ & $\begin{array}{c}\text { Розрахована вартість для відображення } \\
\text { у системі національних рахунків } \\
\text { (з урахуванням землі домашніх } \\
\text { господарств), млрд дол. США }\end{array}$ \\
\hline Рілля (потенціал) & 32,54 & 11,95 & 24,52 \\
\hline \multicolumn{4}{|l|}{ У т. ч.: } \\
\hline $\begin{array}{c}\text { Право оренди } \\
\text { (землі недержавних підприємств) }\end{array}$ & 18,70 & 9,83 & 9,83 \\
\hline Право власності (землі громадян) & 11,66 & $(12,57)$ & 12,57 \\
\hline $\begin{array}{l}\text { Право постійного користування } \\
\text { (землі державних підприємств) }\end{array}$ & 0,77 & 0,75 & 0,75 \\
\hline $\begin{array}{c}\text { Емфітевзис } \\
\text { (інше використання) }\end{array}$ & 1,41 & 1,37 & 1,37 \\
\hline
\end{tabular}

Сьогодні в Україні така політика не ведеться ані на рівні підприємств, ані на рівні держави. Як наслідок, в офіційній фінансовій звітності земельні активи аграрних підприємств України оцінено лише у 151 млн дол. США. Тоді як при застосуванні нової облікової політики цей показник мав би становити 11,95 млрд дол. США, а з урахуванням потенціалу землі товарних господарств (які зараз не ведуть бухгалтерський облік) майже 25 млрд дол. США. Тобто 25 млрд дол. США зростання суми національного багатства України, що представлене у ії системі національних рахунків. Це п’ята частина ВВП та більше ніж весь золотовалютний запас України, який на початок 2019 року знаходився на рівні 20,8 млрд дол. США [6, 7].

Варто зазначити, що зусилля по капіталізації не тільки покращать імідж України, ії підприємництва у світовій статистиці, але і стануть вагомим запобіжником тіньових спекуляцій нею на ринку.

Разом $з$ тим, макроекономічне бачення вартості нашого земельного потенціалу дозволяє сформулювати і глобальне застереження вільного ринку земель. Оцінка нашого земельного багатства натепер склала б лише 2,5 \% капіталізації однієї транснаціональної компанії, такої як Amazon, Microsoft, Alphabet, Apple чи великих банків світового рівня. Валютні резерви більшості країн G-20, нафтопостачальних країн арабських шейхів уже складають по декілька трлн дол. США. Для них вільний ринок земель в Україні - це нові можливості зменшення наслідків періодичних світових економічних криз. Подібну поведінку можна спостерігати і в політиці пенсійних фондів розвинутих країн. Не секрет, що деякі з них вже опосередковано здійснюють землекористування в Україні. Для України, при запуску вільного ринку землі, - це економічний жах неминучого нееквівалентного обміну. Нееквівалентна оцінка і обмін - це жах і для фундаментальної світової і вітчизняної економічної науки. I займаючись капіталізацією земельного багатства, ми з вами, вільно чи не вільно, будемо шукати відповідь і на цей фундаментальний виклик.

Висновки та перспективи подальших досліджень. Таким чином, проведені дослідження доводять необхідність об'єднання зусиль науки і професійної спільноти задля галузевої облікової політики щодо земельних активів сільського господарства. Ї̈̈ запровадження і застосування в Україні - це важливий механізм виокремлення й підняття їх цінності у фінансовій звітності та системі національних рахунків у частині розміру національного багатства України, вартості активів та основного капіталу. Підвищення уваги до земельних активів сільськогосподарського призначення у фінансовій звітності i, як результат, капіталізація національного багатства України видається важливою глобальною перспективою представлення природноекономічного потенціалу України на міжнародній арені. Через цю складову збагачується розвиток i макроекономічної політики. Проведені розрахунки є і глобальним застереженням вільного ринку землі. Представлене дослідження з капіталізації земель сільськогосподарського призначення звертає увагу, що вільний ринок земель у теперішніх економічних умовах не забезпечить гарну ціну землі і одночасно нового продуктивного інвестора. Оскільки він буде визначати свою активність та ціну за поточною дохідністю. Активність і вища ціна для продавця, наразі, можлива лише від олігархічного покупця, потенційного спекулянта землею чи покупця, який розглядає землю як скарб. Натепер капіталізація усієї української сільськогосподарської землі складає лише 2,5 \% від капіталізації однієї транснаціональної корпорації. Наша земля - крапля в морі резервів цих компаній чи багатих країн і їх пенсійних фондів. Зрозуміло, що, потураючи такому шляху, ми лишаємо нашу націю і державу майбутнього.

Список використаної літератури:

1. Agricultural land (\% of land area) [Electronic resourse]. - Access mode https://databank.worldbank.org/reports.aspx? source=2\&series=AG.LND.AGRI.ZS\&country=\#.

2. European System of Accounts (ESA 1995) / Eurostat [Electronic resourse]. - Access mode : https://ec.europa.eu/eurostat/web/products-manuals-and-guidelines/-/KS-02-13-269.

3. Методологічні положення щодо складання балансів активів і пасивів : Наказ Держкомстату № 504 від 10.12.2010 p. [Електронний ресурс]. http://csrv2.ukrstat.gov.ua/metodpolog/metod_doc/2010/504/metod.htm. 
4. Класифікація інституційних секторів економіки України. Статистичний класифікатор України : Наказ Державної служби статистики України № 378 від 03.12.2014 / Державна служба статистики України [Електронний ресурс]. - Режим доступу : https://zakon.rada.gov.ua/rada/show/v0378832-14.

5. Методика експертної грошової оцінки земельних ділянок : Постанова Кабінету Міністрів України № 1531 від 11.10.2002 p. [Електронний ресурс]. - Режим доступу : https://zakon.rada.gov.ua/laws/show/1531-2002-п.

6. Золотовалютный мираж Украины - резервы НБУ на бумаге выглядят весомее, чем в реальности [Электронный ресурс]. - Режим доступа : https://vesti-ukr.com/strana/320605-zolotovaljutnyj-mirazh-ukrainyrezervy-nbu-na-bumahe-vyhljadjat-vesomee-chem-v-realnosti.

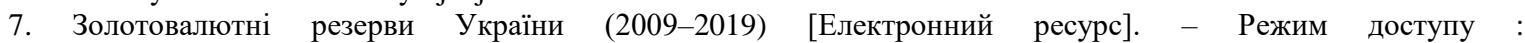
https://index.minfin.com.ua/ua/finance/assets/.

8. Жук В.М. Обіг земель сільськогосподарського призначення за селозберігаючою моделлю аграрного устрою України : наук. доповідь / B.M. Жук ; Національний науковий центр «Інститут аграрної економіки». - К. : ЦП «Компринт», 2017. - $96 \mathrm{c.}$

9. Жук В.М. Капіталізація національного багатства України: землі сільськогосподарського призначення : наук. доповідь / В.М. Жук, Ю.С. Бездушна ; Національний науковий центр «Інститут аграрної економіки». - К. : ЦП «Компринт», 2019. - 40 с.

10. Жук В.M. Місія інституту бухгалтерського обліку в капіталізації національного багатства України : наук. доповідь / В.М. Жук, Ю.С. Бездушна ; Національний науковий центр «Інститут аграрної економіки» - К. : ЦП «Компринт», 2019. - $40 \mathrm{c}$.

11. Zhuk V. Improvement of IFRS application policy in relation to land assets of agricultural enterprises / V.Zhuk, Y.Bezdushna, S.Tyvonchuk // Independent journal of management \& production (IJM\&P). Special Edition PDATU. - Vol. 10, No. 7. - P. 702-724. - DOI: 10.14807/ijmp.v10i7.889. URL: http://www.ijmp.jor.br/ index.php/ijmp/article /view/889.

\section{References:}

1. Agricultural land (\% of land area), [Online], available at: https://databank.worldbank.org/reports.aspx? source $=2 \&$ series $=$ AG.LND.AGRI.ZS\&country $=\#$

2. Eurostat (1995), «European System of Accounts (ESA 1995)», [Online], available at: https://ec.europa.eu/eurostat/web/products-manuals-and-guidelines/-/KS-02-13-269

3. Derzhkomstat (2010), «Metodologichni polozhennja shhodo skladannja balansiv aktyviv i pasyviv», Nakaz, $\begin{array}{llll}\text { No. 504, vid } 10 \text { grudnja, } & \text { [Online], available }\end{array}$ http://csrv2.ukrstat.gov.ua/metod_polog/metod_doc/2010/504/metod.htm

4. Derzhavna sluzhba statystyky Ukrai'ny (2014), «Klasyfikacija instytucijnyh sektoriv ekonomiky Ukrai'ny. Statystychnyj klasyfikator Ukrai'ny», Nakaz, No. 378, vid 3 grudnja, [Online], available at: https://zakon.rada.gov.ua/rada/show/v0378832-14

5. Kabinet Ministriv Ukrai'ny (2002), «Metodyka ekspertnoi' groshovoi' ocinky zemel'nyh diljanok», Postanova, No. 1531, vid 11 zhovtnja, [Online], available at: https://zakon.rada.gov.ua/laws/show/1531-2002-p

6. «Zolotovaljutnyj mirazh Ukrainy - rezervy NBU na bumage vygljadjat vesomee, chem v real'nosti», [Online], available at: https://vesti-ukr.com/strana/320605-zolotovaljutnyj-mirazh-ukrainy-rezervy-nbu-na-bumahevyhljadjat-vesomee-chem-v-realnosti

7. «Zolotovaljutni rezervy Ukrai'ny (2009-2019)», [Online], available at: https://index.minfin.com.ua/ua/finance/assets/

8. Zhuk, V.M. (2017), Obig zemel' sil's'kogospodars'kogo pryznachennja za selozberigajuchoju modellju agrarnogo ustroju Ukrai'ny, nauk. dopovid', Nacional'nyj naukovyj centr «Instytut agrarnoi' ekonomiky», CP «Komprynt», Kyi'v, 96 p.

9. Zhuk, V.M. and Bezdushna, Ju.S. (2019), Kapitalizacija nacional'nogo bagatstva Ukrai'ny zemli sil's'kogospodars'kogo pryznachennja, nauk. dopovid', Nacional'nyj naukovyj centr «Instytut agrarnoi' ekonomiky», $\mathrm{CP}$ «Komprynt», Kyi'v, $40 \mathrm{p}$.

10. Zhuk, V.M. and Bezdushna, Ju.S. (2019), Misija instytutu buhgalters'kogo obliku v kapitalizacii' nacional'nogo bagatstva Ukrai'ny, nauk. dopovid', Nacional'nyj naukovyj centr «Instytut agrarnoi' ekonomiky», CP «Komprynt», Kyi'v, $40 \mathrm{p}$.

11. Zhuk, V., Bezdushna, Y. and Tyvonchuk, S., «Improvement of IFRS application policy in relation to land assets of agricultural enterprises», Independent journal of management \& production (IJM\&P). Special Edition PDATU, Vol. 10, No. 7, pp. 702-724, DOI: 10.14807/ijmp.v10i7.889, URL: http://www.ijmp.jor.br/index.php/ijmp/article /view/889

Жук Валерій Миколайович - доктор економічних наук, професор, академік НААН, головний науковий співробітник «Інституту аграрної економіки».

ORCID iD https://orcid.org/0000-0003-1367-5333

Наукові інтереси:

- інституціональна теорія бухгалтерського обліку.

Бездушна Юлія Сергіївна - кандидат економічних наук, старший науковий співробітник, завідувач відділом обліку та оподаткування Національного наукового центру «Інститут аграрної економіки».

ORCID iD https://orcid.org/0000-0002-5924-0805

Наукові інтереси:

- облік, оцінка, інформаційне забезпечення управління в аграрному секторі економіки. 